\title{
Effects of Propentofylline on Disorder of Learning and Memory in Rodents
}

\author{
Masayoshi GOTO, Nobutaka DEMURA and Takashi SAKAGUCHI
}

Department of Biologica: Science, Research and Development Laboratories, Hoechst Japan Limited, 1-3-2 Minamidai, Kawagoe, Saitama 350, Japan

Accepted August 1, 1987

\begin{abstract}
Effects of a newly synthesized xanthine derivative propentofylline (3,7dihydro-3-methyl-1-(5-oxohexyl)-7-propyl-1H-purine-2.6-dione) on learning and memory of rodents were examined in the two different paradigms. In a shuttle box active avoidance paradigm, propentofylline $(25 \mathrm{mg} / \mathrm{kg} / \mathrm{day}$, p.o.) improved the decreased learning ability of 12 -month-old spontaneously hypertensive rats. Normotensive Wistar-Kyoto rats at a comparable age showed rapid acquisition of avoidance learning. which was not influenced by propentofylline. Stepdown passive avoidance task was carried out as the other paradigm. The protein synthesis inhibitor cycloheximide (CXM) induced amnesia in young adult mice. Propentofylline improved the memory deficit when intraperitoneally administered $30 \mathrm{~min}$ before the retention test. and it also prevented the development of amnesia when injected $15 \mathrm{~min}$ before CXM. These results suggest that propentofylline ameliorates the disturbed learning and memory.
\end{abstract}

Propentofylline (3,7-dihydro-3-methyl-1(5-oxohexyl)-7-propyl-1H-purine-2,6-dione. Fig. 1) is a new xanthine derivative which has been reported to increase cerebral blood flow (1), prevent cerebral metabolic disorder in anoxia (2), and improve cerebral edema (3). These properties imply that propentofylline improves impairment of learning and memory. However, the compound has not been tested in detail for its effects on impaired learning and memory in animals.

The present study was undertaken to examine such effects of propentofylline using two different experimental paradigms.

One was a shuttle box active avoidance

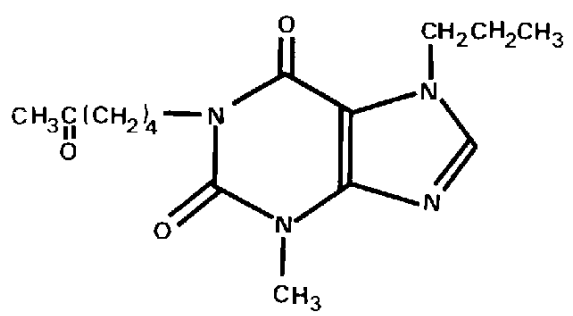

Fig. 1. Chemical structure of propentofylline. task in aged spontaneously hypertensive (SHR) rats. According to the report of Hecht et al. (4). SHR rats showed an age-dependent deciease in active avoidance performance. In addition, administration of a substance $P$ analogue normalized the disorder in the avoidance performance of SHR rats. Their observations suggest that the aged SHR rats are useful for the evaluation of drugs on learning and memory.

The other paradigm used was a step-down passive avoidance task in young adult mice with cycloheximide (CXM) -induced amnesia. Amnesia is known to be caused by protein synthesis inhibitors such as CXM (5-9). The inhibitors are supposed to induce amnesia by interfering with a retrieval process of memory. Therefore, in the passive avoidance task, the effect of the drugs on the retrieval process of the memory can be estimated.

\section{Materials and Methods}

Animals: Twelve-month-old male SHR rats were from our own breeding stock and 12month-old male normotensive Wistar-Kyoto (WKY) rats were purchased at 4 weeks of age 
from Clea Japan, Inc. Six-week-old ICR mice weighing $30-40 \mathrm{~g}$ were obtained from Clea Japan, Inc. The rats and mice were housed 2 and 10 per cage, respectively, in rooms controlled at $23 \pm 1{ }^{\circ} \mathrm{C}$ and $55 \pm 5 \%$ of relative humidity on a 12 -hr light-dark cycle.

Compounds: Compounds used were propentofylline provided by Hoechst Aktiengesellschaft Werk Albert and CXM purchased from Sigma Chemical Co. Propentofylline was dissolved in distilled water and physiological saline for oral and intraperitoneal administration, respectively. CXM was dissolved in physiological saline and injected intraperitoneally at $120 \mathrm{mg} / \mathrm{kg} 15 \mathrm{~min}$ before training in the step-down passive avoidance test.

Shuttle box active avoidance task in SHR rats: The apparatus was a shuttle box purchased from Okazaki Industry Co., Ltd. Each animal was given a session consisting of 25 trials per day for 15 (14 in WKY rats) consecutive days.

The conditioning signal used was a combination of sound and light with a duration of $7.5 \mathrm{sec}$ followed by continued sound and light and a $0.1-4.0 \mathrm{~mA}$ foot shock via the grid floor with a duration of $7.5 \mathrm{sec}$. The inter-trial interval was $15 \mathrm{sec}$. The number of avoidance responses during the warning period preceding the shock was recorded. Propentofylline $(25 \mathrm{mg} / \mathrm{kg})$ was administered orally in a volume of $0.4 \mathrm{ml} / 100 \mathrm{~g} \mathrm{~B} . W$. immediately after each session. The oral route was used to prevent the aged animals from being infected due to 15 -day repeated administration. The dose of $25 \mathrm{mg} / \mathrm{kg}$ was selected because propentofylline at 3 to 30 $\mathrm{mg} / \mathrm{kg}$ had been shown to possess pharmacological actions such as increasing blood flow (1) and improving energy metabolism in the brain of animals (2). The blood pressure of each animal was determined by the tail cuff method after the termination of the study.

Step-down passive avoidance task in mice with CXM-induced amnesia: The test apparatus was a box $(20 \mathrm{~cm}$ wide. $23 \mathrm{~cm}$ long. and $24 \mathrm{~cm}$ high) with an electrifiable grid floor and a platform $(8 \times 8 \times 1.5 \mathrm{~cm})$ in one corner. A mouse was placed on the platform and the original latency was determined. As soon as the animal moved off the platform, a $0.28-\mathrm{mA}$ current was delivered for at least $3 \mathrm{sec}$ to the grid floor until it escaped from the shock. The mouse was allowed to remain on the platform for $8 \mathrm{sec}$, and it was then returned to the grid floor and given a foot shock for at least $5 \mathrm{sec}$. Thirty seconds after the animal jumped back onto the platform, it was removed to its home cage. A retention test was performed $24 \mathrm{hr}$ after acquisition of the passive avoidance response. The testing procedure was the same as for the training except that no foot shock was given. Each mouse was placed once on the platform to test the retention of the learned response. The criterion was whether the animal remained or not for at least $180 \mathrm{sec}$ on the platform. The results were expressed as percent of animals per group that showed the step-down latency of 180 sec or more.

Statistics: The significance of difference between test and control groups was analyzed by the chi-square test. Student's $t$-test and the Mann-Whitney $U$-test.

\section{Results}

Shuttle box active avoidance performance in SHR rats: Figure 2 shows the results in 12-month-old SHR rats. In the controls given saline alone, the number of correct responses remained small through all the sessions. The performance of the treated animals was the same as that of the controls until the 9 th session, but significantly higher at the 10th to 15th sessions except at the 11 th. In 12-month-old WKY rats, propentofylline did not affect avoidance performance; the number of correct responses in the control and treated groups increased at the 6 th to 14 th sessions as shown in Fig. 3 .

After the end of 15th (or 14th) training session, no difference occurred in the blood pressure between the treated and control groups in either SHR or WKY rats (Table 1).

Step-down passive avoidance performance in mice with CXM-induced amnesia: To evaluate the effect of propentofylline on the retrieval process of memory disturbed by CXM. the compound was intraperitoneally administered at doses of 3.8, 7.5, 15 and $30 \mathrm{mg} / \mathrm{kg}$ at $30 \mathrm{~min}$ before the retention test. The 4 doses were determined by the 


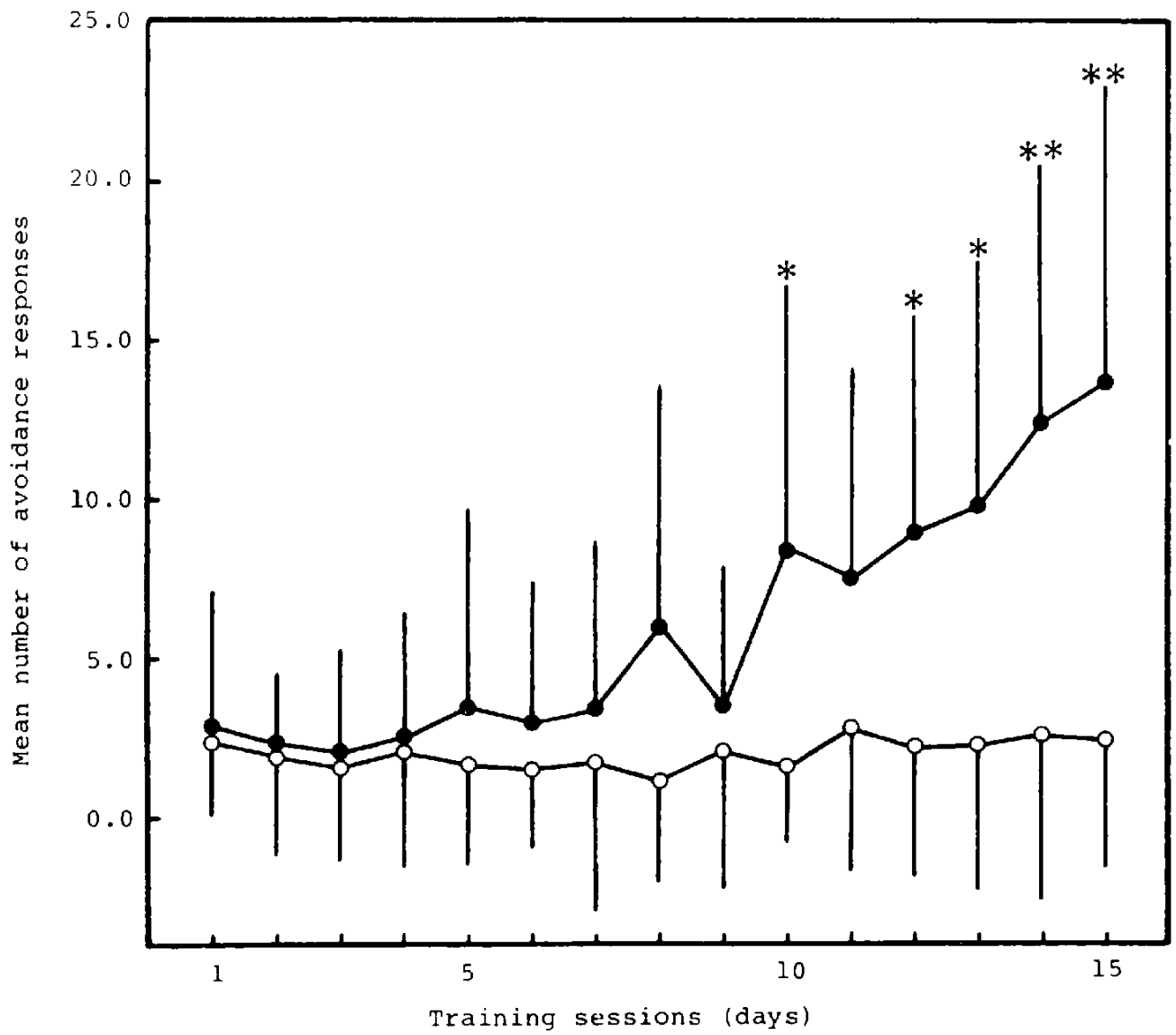

Fig. 2. Effect of propentofylline on shuttle box avoidance performance in 12-month-old male spontaneouly hypertensive rats. Propentofylline $(25 \mathrm{mg} / \mathrm{kg})$ or distilled water was orally given immediately after a training session consisting of 25 trials once a day for 15 days. The number of avoidance responses during the 25 trials was recorded for each rat. The results were expressed as the mean $\pm S . D$. Closed circle, propentofylline $(n=11)$; open circle, control $(n=10)$. " $P<0.05,{ }^{*} P<0.01$ (Mann-Whitney U-test).

preliminary experiment. The results are given in Table 2. The retention in the group given CXM plus saline (10.5\%) was significantly lower than that in the control group given saline alone (49.1\%); that is, amnesia was surely produced by CXM in mice.

The percentages of animals showing passive avoidance in the groups given $7.5,15$ and $30 \mathrm{mg} / \mathrm{kg}$ were, respectively, $31.0,33.3$ and $40.0 \%$, which were all significantly higher than the value for the CXM plus saline group.

To determine whether propentofylline itself had a prolonging effect on the stepdown latency, it was administered at 30 $\mathrm{mg} / \mathrm{kg}$ to naive mice, and then their stepdown latency was measured $30 \mathrm{~min}$ later. Their latency expressed as the mean \pm S.D. (7.6 \pm 3.9 sec, $n=22)$ did not significantly differ from that of untreated control animals $(11.8 \pm 6.1$ sec, $n=20)$ when analyzed by Student's $t$-test, at $P<0.01$.

Propentofylline was intraperitoneally administered at doses of 15 and $30 \mathrm{mg} / \mathrm{kg} 15$ min before CXM to determine whether it prevented CXM-induced amnesia. The results are shown in Table 3 . Retention performance in the group given saline plus CXM $(12.5 \%)$ was significantly lower than that in the control group given saline alone 


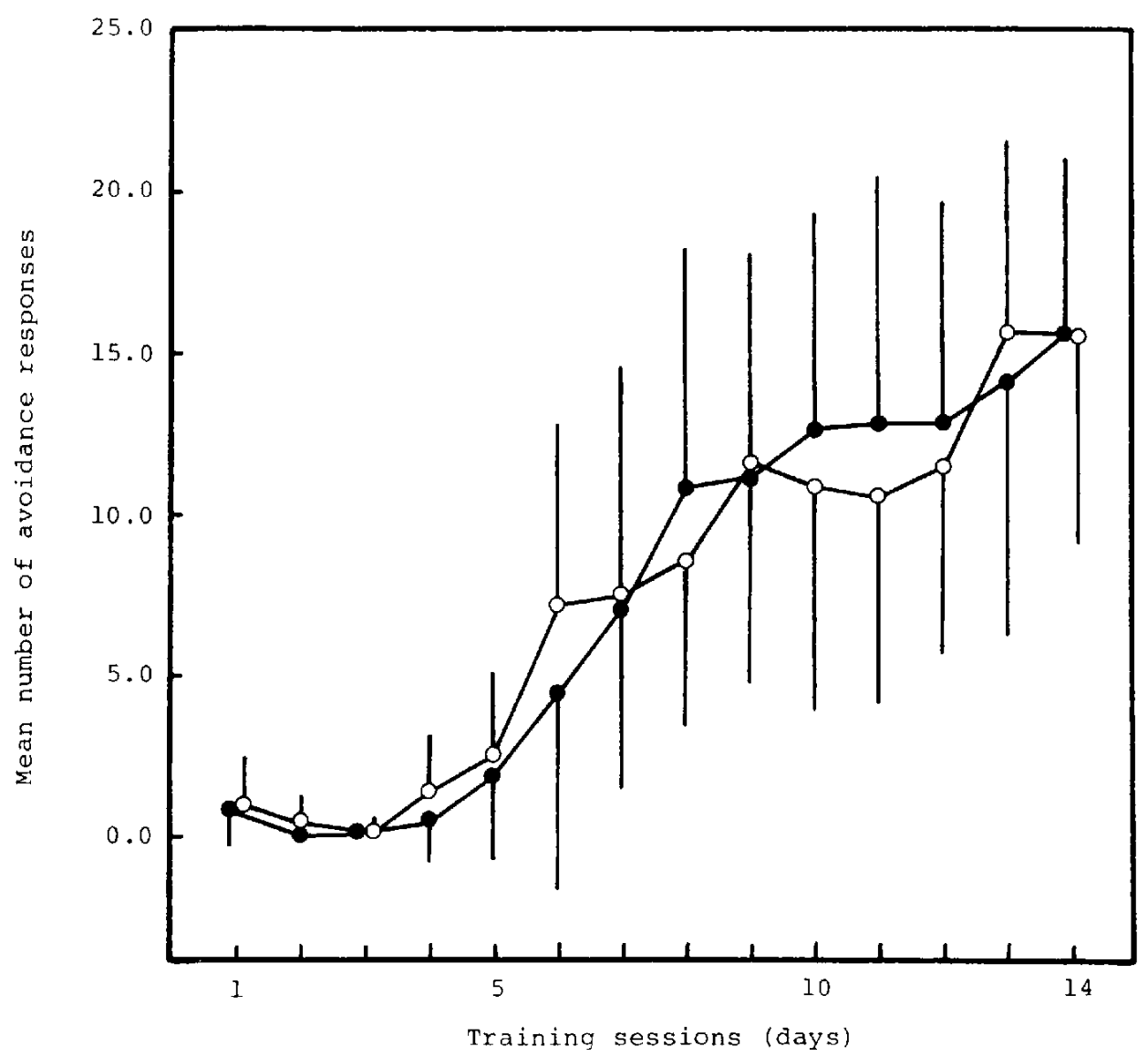

Fig. 3. Effect of propentofylline on shuttle box avoidance performance in 12 -month-old male WistarKyoto rats. The experimental procedures were the same as in Fig. 2 except that the compound was administered for 14 days. Closed circle, propentofylline $(n=9)$; open circle, control $(n=8)$.

Table 1. Blood pressure $(\mathrm{mmHg})$ of spontaneously hypertensive (SHR) and Wistar-Kyoto (WKY) rats at 12 months of age after study of propentofylline for its effect on shuttle-box avoidance performance

\begin{tabular}{ccc}
\hline Rats & $\begin{array}{c}\text { Control } \\
\text { (Distilled water) }\end{array}$ & Propentofylline \\
\hline SHR & $163.6 \pm 26.0(10)$ & $164.3 \pm 23.0(11)$ \\
WKY & $117.4 \pm 9.2(8)$ & $122.6 \pm 14.6(9)$ \\
\hline
\end{tabular}

Values represent the mean $\pm S$.D. and parenthesized figures, the number of animals used.

(68.4\%). The percentages of mice acquiring the learned task were 35.1 and $37.1 \%$ at 15 and $30 \mathrm{mg} / \mathrm{kg}$, respectively. The values were both significantly higher than that for the saline plus CXM group, indicating that propentofylline prevented the amnestic effect of CXM.

\section{Discussion}

Learning ability of 12-month-old SHR rats was decreased in the shuttle box active avoidance paradigm. compared with that of 12 -month-old WKY rats. Our findings are consistent with the report that SHR rats showed lower performance than Wistar rats 
Table 2. Improving effect of propentofylline on cycloheximide (CXM)-induced amnesia for step-down avoidance task in mice

\begin{tabular}{lccc}
\hline Group & $\begin{array}{c}\text { Dose } \\
(\mathrm{mg} / \mathrm{kg})\end{array}$ & $\begin{array}{c}\text { No. of } \\
\text { animals }\end{array}$ & $\begin{array}{c}\text { Percent retention } \\
24 \text { hr after training }\end{array}$ \\
$\begin{array}{l}\text { Control } \\
\text { (Saline+saline) }\end{array}$ & - & 53 & 49.1 \\
CXM+saline & - & 57 & $10.5^{*}$ \\
CXM+propentofylline & 3.8 & 30 & $10.0^{*}$ \\
CXM+propentofylline & 7.5 & 29 & $31.0^{*}$ \\
CXM+propentofylline & 15.0 & 27 & $33.3^{*}$ \\
CXM + propentofylline & 30.0 & 35 & $40.0^{* *}$ \\
\hline
\end{tabular}

CXM was intraperitoneally injected at $120 \mathrm{mg} / \mathrm{kg} 15 \mathrm{~min}$ before training. Propentofylline was intraperitoneally administered $30 \mathrm{~min}$ before the retention test. which was performed $24 \mathrm{hr}$ after training. tSignificantly different from the saline+saline group at $\mathrm{P}<0.01$. "Significantly different from the $\mathrm{CXM}+$ saline group at $P<0.05$, "*Significantly different from the $C \times M+$ saline group at $P<0.01$ (chi-square test).

Table 3. Preventive effect of propentofylline on amnesia induced by cycloheximide (CXM) for stepdown avoidance task in mice

\begin{tabular}{lccc}
\hline \multicolumn{1}{c}{ Group } & $\begin{array}{c}\text { Dose } \\
(\mathrm{mg} / \mathrm{kg})\end{array}$ & $\begin{array}{c}\text { No. of } \\
\text { animals }\end{array}$ & $\begin{array}{c}\text { Percent retention } \\
24 \text { hr after training }\end{array}$ \\
$\begin{array}{l}\text { Control } \\
\text { (Saline+saline) }\end{array}$ & - & 19 & 68.4 \\
Saline+CXM & - & 40 & $12.5 \dagger$ \\
Propentofylline +CXM & 15.0 & 37 & $35.1^{*}$ \\
Propentofylline+CXM & 30.0 & 35 & $37.1^{*}$ \\
\hline
\end{tabular}

CXM was intraperitoneally injected at $120 \mathrm{mg} / \mathrm{kg} 15 \mathrm{~min}$ before training. Propentofylline was intraperitoneally administered $30 \mathrm{~min}$ before training (i.e.. $15 \mathrm{~min}$ before CXM). TSignificantly different from the saline+saline group at $P<0.01$. "Significantly different from the saline $+C X M$ group at $P<0.05$ (chi-square test).

in lever press avoidance performance (4). The reason why the aged SHR rats showed a lower ability of learning is not clear: however, it is thought to be caused by chronic hypertension.

The successive administration of propentofylline (25 mg/kg/day, p.o.) could improve the learning of SHR rats in the shuttle box active avoidance performance, but the compound had no effect on the performance of WKY rats (Fig. 3). There may be a possibility that propentofylline had an increasing effect on rat spontaneous activity and that only the improving effect on learning noted was apparent. However, this possibility can be excluded because our kinetic studies in rats (10) revealed that (a) the biological half of propentofylline in the blood was about $30 \mathrm{~min}$ and (b) almost $90 \%$ of the compound was excreted into urine and feces within $24 \mathrm{hr}$. In the present study, propentofylline was administered immediately after each test session and intervals between the sessions were $24 \mathrm{hr}$; it is reasonable to suppose that propentofylline did not affect rat spontaneous activity. Actually. SHR rats acquired the shuttle box avoidance task gradually with advanced sessions, indicating that the compound improved the lowered performance of aged SHR rats.

In the passive avoidance paradigm, propentofyline improved and prevented dosedependently CXM-induced amnesia (Tables 2 and 3). Since memory deficit induced by protein synthesis inhibitors such as CXM was temporal $(5,11,12)$ and since the disturbed memory of experimental animals was recovered by the various manipulations $(13-17)$, the amnesia is supposed to be induced by interference with a retrieval process of memory. Our observations mean 
that the antiamnestic effect of propentofylline is involved in the activation of the retrieval process of memory.

Our findings that propentofylline improved the disorder of learning and memory in rodents suggest the possibility that the compound may be a therapeutic agent for disturbed learning and memory.

Further investigations including that for the possible relation between behavioral effects and pharmacological profiles of propentofylline such as increasing blood flow. protecting metabolic disorder, and improving edema in CNS will be needed to elucidate the mode of action of the compound on learning and memory.

\section{References}

1 Hadlicka, O., Komarek, J. and Wright, A.J.A.: The effect of a xanthine derivative. 1-( $5^{\circ} \circ \times 0$ hexyl)-3-methyl-7-propylxanthine (HWA 285). on heart performance and regional blood flow in dogs and rabbits. Br. J. Pharmacol. 72, 723-730 (1981)

2 Stefanovich, V. and Nagata, K.: Effect of propentofylline and cinepazide on cerebral energy metabolism in nitrogen breathing rats. IRCS Med. Sci. 11, 972 (1983)

3 Mrsulja, B.B., Micic, D.V. and Djuricic, B.M.: Gerbil stroke model: an approach to the study of therapeutic aspects of postischemic brain edema. Adv. Biosci. 43, 45-62 (1983)

4 Hecht, K., Oehme, P., Poppei, M., Hecht, T., Moritz, $V$. and Hilse, $H$.: Effects of a substance $P$-analogue on blood pressure and avoidance learning of rats with spontaneous hypertension. Acta Physiol. Pharmacol. Bulg. 6, 60-65 (1980)

5 Flexner, L.B., Flexner, J.B. and Roberts, R.B.: Stages of memory in mice treated with acetoxycycloheximide before or immediately after learning. Proc. Natl. Acad. Sci. U.S.A. 56, 730735 (1966)

6 Barondes, S.H. and Cohen, H.D.: Delayed and sustained effect of acetoxycycloheximide on memory in mice. Proc. Natl. Acad. Sci. U.S.A. $58,157-164$ (1967)
7 Flood, J.F., Rosenzweig, M.R., Bennett, E.L. and Orme, A.E.: Influence of training strength on amnesia induced by pretraining injections of cycloheximide. Physiol. Behav. 9, 589-600 (1972)

8 Flood, J.F., Rosenzweig, M.R., Bennett, E.L. and Orme, A.E.: The influence of duration of protein synthesis inhibition on memary. Physiol. Behav. 10. 555-562 (1973)

9 Flood, J.F., Bennett, E.L., Orme, A.E. and Rosenzweig, M.R.: Relation of memory formation to controlled amounts of brain protein synthesis. Physiol. Behav. 15, 97-102 (1975)

10 Macdonald, C.M., Gebert, U., Watson, K., Bryce, T.A. and Omosu, $M_{1:}$ The excretion and metabolism of ${ }^{14} \mathrm{C}$-HWA 285 in rat and dog. Japan. Pharmacol. Ther. 14, 37-48 (1986)

11 Serota, R.G.: Acetoxycycloheximide and transient amnesia in the rat. Proc. Natl. Acad. Sci. U.S.A. 68, 1249-1250 (1971)

12 Squire, L.R. and Barondes, S.H.: Variable decay of memory and its recovery in cycloheximidetreated mice. Proc. Natl. Acad. Sci. U.S.A. 69, 1416-1420 (1972)

13 Flood, J.F., Jarvik, M.E., Bennett, E.L., Orme, A.E. and Rosenzweig, M.R.: The effect of stimulants, depressants, and protein synthesis inhibition on retention. Behav. Biol. 20, 168-183 (1977)

14 Flood, J.F., Bennett, E.L., Orme, A.E., Rosenzweig, M.R. and Jarvik, M.E.: Memory: Modification of anisomycin-induced amnesia by stimulants and depressants. Science 199, 324-326 (1978)

15 Flood, J.F., Vidal, D., Bennett, E.L., Orme, A.E.r Vasques, S. and Jarvik, M.E.: Memory facilitating and anti-amnesic effects of corticosteroids. Pharmacol. Biochem. Behav. 8, 81-87 (1978)

16 Cumin, R., Bandle, E.F., Gamzu, E. and Haefely, W.E.: Effects of the novel compound aniracetam (Ro 13-5057) upon impaired learning and memory in rodents. Psychopharmacology (Berlin) 78, 104-111 (1982)

17 Quartermain, D., Freedman, L.S., Botwinick, C.Y. and Gutwein, B.M.: Reversal of cycloheximide-induced amnesia by adrenergic receptor stimulation. Pharmacol. Biochem. Behav. 7. 259-267 (1977) 